\title{
Antioxidant and antimicrobial activities of a purified polysaccharide from yerba mate (Ilex paraguariensis)
}

\author{
Pâmela T.A.N. Kungel a , Vanesa G. Correa a , Rúbia C.G. Corrêa a , Rosely Aparecida Peralta ${ }^{\text {b }}$, Marina Soković ${ }^{\text {c }}$, \\ Ricardo C. Calhelha ${ }^{\mathrm{d}}$, Adelar Bracht ${ }^{\mathrm{a}}$, Isabel C.F.R. Ferreira ${ }^{\mathrm{d}, *}$, Rosane M. Peralta ${ }^{\mathrm{a}, * *}$ \\ a Department of Biochemistry, and Post-graduate Program of Food Science, State University of Maringá, Paraná, Brazil \\ b Department of Chemistry, Federal University of Santa Catarina, Santa Catarina, Brazil \\ c University of Belgrade, Department of Plant Physiology, Institute for Biological Research "Siniša Stanković", Belgrade, Serbia \\ d Mountain Research Centre (CIMO), Polytechnic Institute of Bragança (IPB), Campus de Santa Apolonia, Bragança, Portugal
}

\section{A R T I C L E I N F O}

\section{Article history:}

Received 19 February 2018

Received in revised form 21 March 2018

Accepted 4 April 2018

Available online 6 April 2018

\section{Keywords:}

Antioxidant activity

Antimicrobial activity

Polysaccharide

Yerba mate

\begin{abstract}
A B S T R A C T
This study investigated the antioxidant, antimicrobial and cytotoxic properties of a purified yerba mate polysaccharide. The yerba mate polysaccharide showed a prominent antioxidant activity as evaluated by 2,2-diphenyl-1picrylhydrazyl ( $\mathrm{DPPH} \bullet$ )-radical scavenging activity $\left(\mathrm{IC}_{50}=1.25 \pm 0.10 \mathrm{mg} / \mathrm{mL}\right)$, 3-ethyl benzothiazoline-6sulphonic acid (ABTS•+)-radical scavenging activity $\left(\mathrm{IC}_{50}=0.41 \pm 0.05 \mathrm{mg} / \mathrm{mL}\right)$, and hydroxyl scavenging activity $\left(\mathrm{IC}_{50}=3.36 \pm 0.31 \mathrm{mg} / \mathrm{mL}\right.$ ). The antioxidant activity evaluated as the ferric ion reduction power (FRAP) and oxygen radical absorbance radical assay (ORAC), expressed as trolox equivalents, were $20.84 \pm 1.61 \mu \mathrm{M} \mathrm{TE} /-$ $\mathrm{mg}$ and $556.30 \pm 12.83 \mu \mathrm{M} \mathrm{TE} / \mathrm{mg}$, respectively. The purified yerba mate polysaccharide presented high antimicrobial activity against several bacterial and fungal strains; however, no cytotoxicity against all four tumor human cell lines assessed.
\end{abstract}

(c) 2018 Elsevier B.V. All rights reserved.

\section{Introduction}

The yerba mate (YM) (Ilex paraguariensis A. St. Hil.) is a plant that grows naturally in Paraguay, Uruguay, Argentina and Brazil. The powder of YM leaves and thin stems is used for the preparation of several stimulant drinks. The three most important forms of consumption are chimarrão (hot water extract of green dried leaves; mate in Spanish speaking countries), tererê (cold water extract of green dried leaves) and mate tea (hot water extract of toasted leaves) [1,2].

The yerba mate is associated with numerous health benefits among which it is important to mention its antioxidant properties $[3,4]$ vasodilators properties [5,6], hypoglycemic effects $[7,8]$ and fat loss properties [9]. Different chemical components responsible for the yerba matebased beverages' positive health outcomes have been identified, such as vitamins, minerals, polyphenols, xanthines, saponins, phenolic compounds, amino acids, enzymes, cellulose, lignin and organic acids [10].

The biological and functional properties of yerba mate are frequently associated with compounds from secondary metabolism. Yerba mate is

\footnotetext{
* Corresponding author

** Correspondence to: R. M. Peralta, Department of Biochemistry, Universidade Estadual de Maringá, Maringá, PR, Brazil.

E-mail addresses: iferreira@ipb.pt (I.C.F.R. Ferreira), rmperalta@uem.br (R.M. Peralta).
}

known to be rich in phenolic acids such as caffeic and chlorogenic acids and their derivatives, in addition to flavan-3-ols such as ( + )-catechin $[11,12]$. Other compounds frequently found in the extracts are: gallic, syringic, ferulic and $p$-coumaric acids, rutin, methylxanthines (caffeine and theobromine), saponins and tannins [1,8]. A few years ago, a polysaccharide from yerba mate leaves was purified and its chemical structure identified as a rhamnogalacturonan I (RG-I) with a main chain of $\rightarrow 4)-6-O M e-\alpha$-d-GalpA-( $1 \rightarrow$ groups, interrupted by $\alpha$-l-Rhap units, substituted by a type I arabinogalactan (Fig. 1) [13]. This RG-I presented an anti-inflammatory action demonstrated by its capability of decreasing tissue expression of inducible nitric oxide synthase (iNOS) and cyclooxygenase-2 (COX-2) and a potential adjuvant action in sepsis treatment [13]. In addition to this, the yerba mate RG-I was able to inhibit the gastric lesions induced by ethanol in rats [14].

In the past years, the scientific community has been increasingly interested in the investigation of natural polysaccharides from different sources, including rhamnogalacturonan-I (RG-I) and rhamnogalacturonan-II (RG-II) type pectins, owing to their promising pharmacological and biological activities [15-20]. Based on these considerations, efforts to enlarge the spectrum of the biological actions attributable to the yerba mate RG-I are quite interesting and desirable. Thus, the aim of the present work was to evaluate the antioxidant, antimicrobial and cytotoxic potentials against tumoral cells and porcine liver cells of this polysaccharide. 


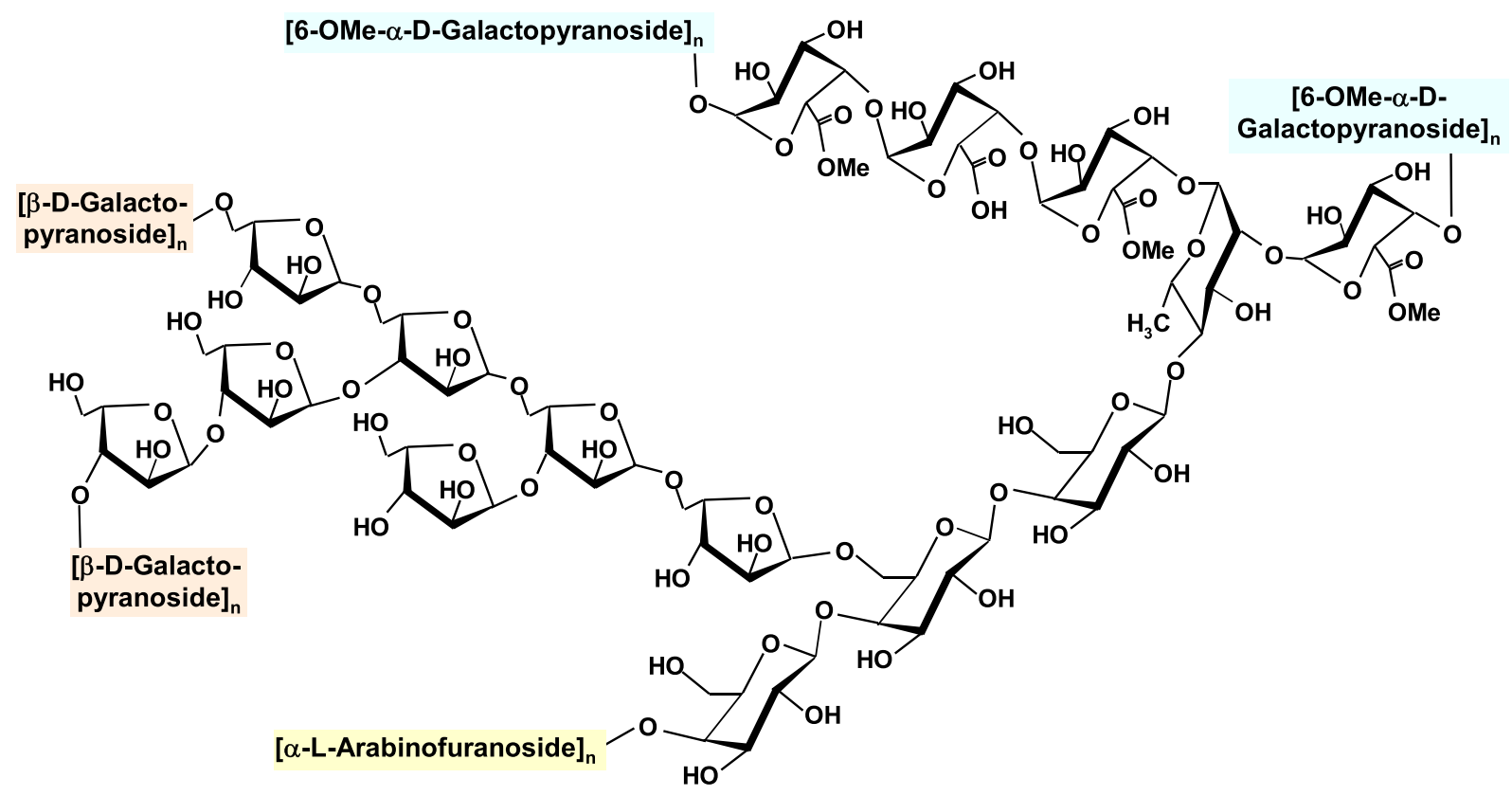

Fig. 1. Structure of the YM purified polysaccharide (rhamnogalacturonan I), according to Dartora et al. (2013) [13].

\section{Material and methods}

\subsection{Plant material}

I. paraguariensis A. St. Hil. plant (dry leaves and stems, stored at vacuum) was obtained from a reliable producer in Southern Brazil. The plant was collected during the January crop of 2016. The region of production presents subtropical climate, average altitude of $923.5 \mathrm{~m}$ and during 2016 the registered rainfall was of $800-1800 \mathrm{~mm}$. The material was ground using an electric grinder and the standardization of granulometry was made by sieves of 20 mesh. The obtained powder was stored in a desiccator at room temperature (average $25^{\circ} \mathrm{C}$ ), and protected from light, until further analysis.

\subsection{Standards and reagents}

Ethanol, chloroform, butanol, anthrone, rhamnose, sulfuric acid, sodium carbonate, Bradford reagent, 2,2-diphenyl-1-picrylhydrazyl (DPPH), Folin-Ciocalteau reagent, ascorbic acid, methanol, 2,4,6tripyridyl-s-triazine (TPTZ), hydrochloric acid, ferric chloride, 3-ethyl benzothiazoline-6-sulphonic acid (ABTS), potassium persulfate, salicylic acid, iron sulphate, 6-hydroxy-2,5,7,8-tetramethylchromane2-carboxylic acid (TROLOX), 2,2-azobis (2-amidinopropane) dihydrochloride (AAPH), fluorescein, dialysis membrane (7000 Da) were purchased from Sigma-Aldrich Co (St Louis, MO). RPMI-1640, Dulbecco's modified Eagle's medium (DMEM), Hank's balanced salt solution (HBSS), fetal bovine serum (FBS), L-glutamine, trypsin-EDTA, penicillin/streptomycin solution $(100 \mathrm{U} / \mathrm{mL}$ and $100 \mathrm{mg} / \mathrm{mL}$, respectively) were purchased from Gibco Invitrogen Life Technologies (California, USA). All other general laboratory reagents were purchased from Panreac Quimica S.L.U. (Barcelona, Spain). Water was treated in a Milli-Q water purification system (TGI Pure Water Systems, USA). All other reagents used in the experiments were of analytical grade.

\subsection{Polysaccharide extraction and purification}

One hundred (100) g of dried powdered mate were extracted three times with $500 \mathrm{~mL}$ of ethanol (70\%) for $3 \mathrm{~h}$ at room temperature and agitation of $120 \mathrm{rpm}$ to remove low molecular weight compounds and for depigmentation. The sample was filtered and the procedure was repeated three times. Insoluble material was dried to remove ethanol completely. The polysaccharide was extracted and purified from the insoluble material as previously described [13] with some modifications. The residue of the extraction was dissolved in distilled water and subjected to a hot extraction at $80{ }^{\circ} \mathrm{C}$, for $15 \mathrm{~min}$. Thereafter the extract was autoclaved for $20 \mathrm{~min}$. The soluble fraction was precipitated with 3 volumes of ethanol and kept overnight in the refrigerator. The material was centrifuged at $4000 \mathrm{rpm}$ for $15 \mathrm{~min}$, and the precipitate redissolved in distilled water. To remove the protein fraction, the material was treated using the Sevag method [21]. The material was precipitated with 3 volumes of ethanol for $24 \mathrm{~h}$ and centrifuged at $4000 \mathrm{rpm}$ for $15 \mathrm{~min}$. The precipitate was re-dissolved in a small volume of distilled water and dialyzed for $24 \mathrm{~h}$ against distilled water. To remove DNA contamination, a volume of $4 \mathrm{~mL}$ DNAse solution $(2 \mathrm{U} / \mathrm{mL}$ in $100 \mathrm{mM}$ Tris buffer, $\mathrm{pH} 7.5$, containing $25 \mathrm{mM} \mathrm{MgCl}_{2}$ and $5 \mathrm{mM} \mathrm{CaCl}_{2}$ ) was added to the polysaccharide solution, and the mixture was incubated at $37^{\circ} \mathrm{C}$ for $20 \mathrm{~min}$. The DNA-free polysaccharide was precipitated with ethanol, centrifuged and dialyzed. Finally, the polysaccharide was lyophilized, weighed, and stored at $-20^{\circ} \mathrm{C}$ for further analysis.

\subsection{Chemical analysis}

The presence of phenolics and proteins in the yerba mate polysaccharide was evaluated by using the Folin-Ciocalteu method [22] and Bradford's method [23], respectively. For the first determination, a standard curve was constructed using gallic acid and the results were expressed as gallic acid equivalents/mg of material. For the evaluation of protein, bovine serum albumin was used as a standard and the results were expressed as albumin equivalents $(\mathrm{AE}) / \mathrm{mg}$ of material.

\subsection{Ultraviolet-visible (UV-Vis) and Fourier transform infrared (FTIR) spectroscopy}

The purified yerba mate polysaccharide was re-dissolved in water to obtain a concentration of $0.25 \mathrm{mg} / \mathrm{mL}$. The UV-Vis spectra of the solution between 190 and $800 \mathrm{~nm}$ were then recorded using a spectrophotometer (Beckman Coulter DU640 B, USA). Prior to FTIR analysis, the polysaccharide was dried and desiccated in a vacuum jar. Thereafter, 
an amount of $2 \mathrm{mg}$ of the dried sample was mixed with $200 \mathrm{mg} \mathrm{KBr}$ of spectroscopic grade and compressed into pellets at a pressure of about $1 \mathrm{MPa}$. Sample spectra were obtained in triplicates using an average of 128 scans in the range between $500 \mathrm{~cm}^{-1}$ and $4000 \mathrm{~cm}^{-1}$ with a spectral resolution of $2 \mathrm{~cm}^{-1}$. Peak heights and areas of the FTIR spectra were determined by means of the Opus software version 6.5 normalized by maximum and minimum peaks.

\subsection{Biological activities}

\subsubsection{Antioxidant activity evaluation}

Five different methods were used to evaluate the antioxidant activity of the YM polysaccharide: reduction power of the ferric ion (FRAP), oxygen radical absorbance radical assay (ORAC), reduction of the 2,2diphenyl-1-picrylhydrazyl radical (DPPH•), reduction of the 2,2-azinobis (3-ethylbenzothiazoline-6-sulphonate) cation (ABTS•+), and hydroxyl radical scavenging activity. Successive dilutions of the stock solution were made and used for assaying the antioxidant activity of the sample. FRAP and ORAC were evaluated as described previously [24]. Standard curves were constructed with trolox $\left(r^{2}=0.99\right)$ and the results were expressed as mmol trolox equivalents (TE)/mg lyophilisate material. The DPPH and the ABTS assays were conducted as described previously [25]. The lyophilisate concentrations $(\mathrm{mg} / \mathrm{mL})$ providing $50 \%$ antioxidant activity were calculated from the graphs of antioxidant activity against the sample concentrations. Trolox was used as a positive control and water was used as negative control. The results were expressed as $\mathrm{IC}_{50}$ values (sample concentration providing $50 \%$ of antioxidant activity). The hydroxyl radical scavenging activity of the YM polysaccharide was measured having as principle the Fenton's reaction [21]. The results were also expressed as $\mathrm{IC}_{50}$ values. Ascorbic acid was used as positive control whereas the negative control was water.

\subsubsection{Antimicrobial activity evaluation}

For antibacterial activity assay, the following Gram-negative bacteria were chosen: Escherichia coli (ATCC 35210), Salmonella enteritidis (ATCC), Salmonella typhimurium (ATCC 13311), Enterobacter cloacae (ATCC 35030), along with the following Gram-positive bacteria: Staphylococcus aureus (ATCC 6538), Bacillus cereus (clinical isolate), Micrococcus flavus (ATCC 10240), and Listeria monocytogenes (NCTC 7973). For the antifungal tests the following microfungi were assessed: Aspergillus fumigatus (1022), Aspergillus ochraceus (ATCC 12066), Aspergillus versicolor (ATCC 11730), Aspergillus niger (ATCC 6275), Candida crusei (human isolate), Penicillium funiculosum (ATCC 36839) and Penicillium verrucosum var. cyclopium (food isolate). In order to investigate the antimicrobial potential of the YM polysaccharide against these foodborne pathogens and spoilage agents, a modified microdilution technique was applied [26]. Minimum inhibitory concentration (MIC) determinations were performed by a serial dilution technique using 96-well microtiter plates. Both minimum bactericidal (MBCs) and minimum fungicidal (MFCs) concentrations were determined by serial subcultivation of a $2 \mathrm{~mL}$ sample into microtiter plates containing $100 \mathrm{~mL}$ of broth per well and further incubation for $48 \mathrm{~h}$ at $37^{\circ} \mathrm{C}$ or $72 \mathrm{~h}$ at $28^{\circ} \mathrm{C}$, as previously described [27]. The lowest concentrations with no visible growth were nominated as MBC/MFC, corresponding to $99.5 \%$ killing of the original inoculum. In the antibacterial bioassays, streptomycin (ICNGalenika, Belgrade, Serbia) and ampicillin (Panfarma, Belgrade, Serbia) were used as positive controls, while in antifungal tests the commercial fungicides bifonazole (Srbolek, Belgrade, Serbia) and ketoconazole (Zorkapharma, Sabac, Serbia) were applied (at the concentration of $1 \mathrm{mg} / \mathrm{mL}$ in sterile physiological saline); $30 \%$ ethanol was employed as negative control.

\subsubsection{Cytotoxicity in human tumor cell lines}

Four human tumor cell lines were used: MCF-7 (breast adenocarcinoma), NCI-H460 (non-small cell lung cancer), HeLa (cervical carcinoma) and HepG2 (hepatocellular carcinoma). Cells were routinely maintained as adherent cell cultures in RPMI-1640 medium containing 10\% heat-inactivated FBS and $2 \mathrm{mM}$ glutamine (MCF-7, NCI-H460 HeLa and HepG2 cells), at $37^{\circ} \mathrm{C}$, in a humidified air incubator containing $5 \%$ $\mathrm{CO}_{2}$. Each cell line was plated at an appropriate density $\left(1.0 \times 10^{4}\right.$ cells/well) in 96-well plates. The sulforhodamine B assay was performed according to a procedure previously described by the authors [28]. Ellipticine was used as positive control.

\subsubsection{Cytotoxicity in non-tumor liver cells primary culture}

A cell culture was prepared from a freshly harvested porcine liver obtained from a local slaughter house, according to a procedure established by the authors [29]. It was designated as PLP2. Cultivation of the cells was continued with direct monitoring every two to three days using a phase contrast microscope. Before confluence was reached, cells were sub-cultured and plated in 96-well plates at a density of 1.0 $\times 10^{4}$ cells/well, and commercial in DMEM medium with $10 \% \mathrm{FBS}$, $100 \mathrm{U} / \mathrm{mL}$ penicillin and $100 \mu \mathrm{g} / \mathrm{mL}$ streptomycin. Ellipticine was used as positive control.

\subsection{Statistical analysis}

Three repetitions of the sample and triplicates for each concentration were carried out in all assays. The results were reported as mean \pm standard error. The $\mathrm{IC}_{50}$ values and graphics were obtained from the logarithmic non-linear regression curve derived from the plotted data using the GraphPad Prism software (version 5.0).

\section{Results and discussion}

\subsection{Yield and structural analysis of yerba mate polysaccharide}

In order to obtain the pure polysaccharide previously illustrated by Fig. 1 [13], the sequential methods shown in Fig. 2 were used. An amount of $1.2 \mathrm{~g}$ of the dried pure polysaccharide was obtained starting from $100 \mathrm{~g}$ of yerba mate. Phenolics and proteins were not detected by chemical methods. In addition, the UV-Vis spectrum of the yerba mate polysaccharide showed no absorption peaks at 260 and $280 \mathrm{~nm}$ (Fig. 3). Significant contamination by proteins, peptides, DNA and phenolics is thus unlikely.

FTIR spectroscopy is usually used for identifying characteristic organic groups in the polysaccharide. As illustrated by Fig. 4, vibrations and glycosidic bonds typical of polysaccharide structures are apparent. The absorption peak at $767 \mathrm{~cm}^{-1}$ indicates the presence of pyranoses in $\alpha$-configuration [30]. The absorption at $1072 \mathrm{~cm}^{-1}$ can be attributed to the stretching vibration of the $\mathrm{C}-\mathrm{O}-\mathrm{C}$ glycosidic bond vibrations and side group $\mathrm{C}-\mathrm{O}-\mathrm{H}$ link bonds [31]. The spectrum shows absorption bands at 1013, 1076 and $1100 \mathrm{~cm}^{-1}$, which are characteristic of pectin polymers. The rhamnogalacturonan structure can be confirmed by the stretching vibration bands of the ester carbonyl at 1610 and $1737 \mathrm{~cm}^{-1}$ corresponding to asymmetric carbonyl stretching of carboxylate groups, overlapped by the water absorption band. The bands around $1442 \mathrm{~cm}^{-1}$ and $1374 \mathrm{~cm}^{-1}$ for $\mathrm{C}-\mathrm{H}$ band stretching are due to asymmetric and symmetric bending vibrations, respectively [32]. The band at $1609 \mathrm{~cm}^{-1}$ can be attributed to the $\mathrm{C}=0$ stretching vibration of uronic acid [33]. Strong and wide absorption bands at about $2800-3500 \mathrm{~cm}^{-1}$ for $\mathrm{C}-\mathrm{H}$ and $\mathrm{O}-\mathrm{H}$ stretching vibrations and the strong absorption in the region of $1000-1125 \mathrm{~cm}^{-1}$ indicates the presence of the functional groups $\mathrm{C}-\mathrm{OH}, \mathrm{C}-\mathrm{O}-\mathrm{C}$ and $\mathrm{C}-\mathrm{C}$ [34].

\subsection{Antioxidant activities of the yerba mate polysaccharide}

In vitro antioxidant models are based on the transfer of a single electron $(\mathrm{DPPH} \bullet, \mathrm{ABTS} \bullet+, \mathrm{FRAP})$ or the transfer of hydrogen atoms (hydroxyl and ORAC) [35]. The results of three assays, DPPH, ABTS, and hydroxyl radical scavenging activities, are shown in Fig. 5. The $\mathrm{IC}_{50}$ values of the scavenging activities were $1.25 \pm 0.10 \mathrm{mg} / \mathrm{mL}, 0.41 \pm$ 


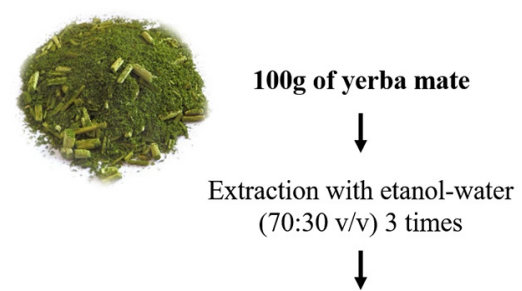

Hot extraction at $80^{\circ} \mathrm{C}$ for $15 \mathrm{~min}$

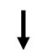

Autoclaved at $120^{\circ} \mathrm{C}$ for $20 \mathrm{~min}$

$\downarrow$ Filtrate Residue (discarded)

Precipitation with 3 volumes of ethanol overnight

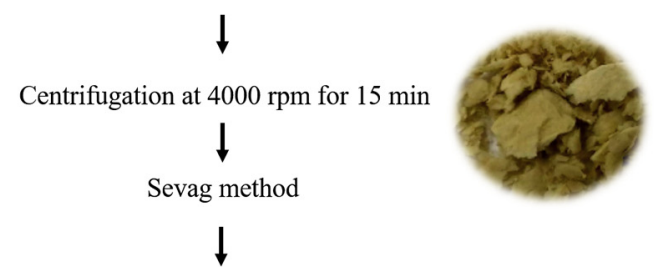

Centrifugation at $4000 \mathrm{rpm}$ for $15 \mathrm{~min}$

Dialysis for $24 \mathrm{~h}$

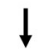

DNase

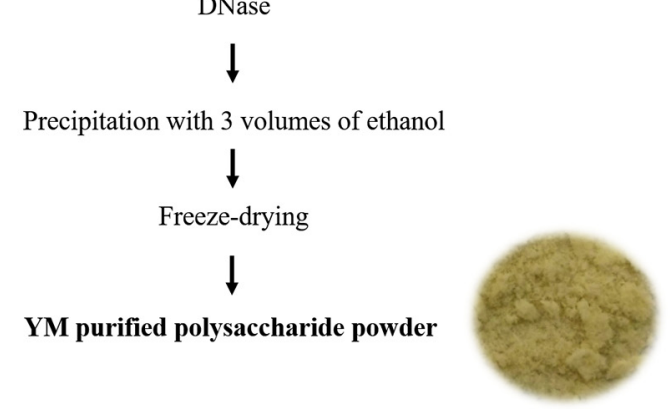

Fig. 2. Diagram for the obtainment of purified yerba mate polysaccharide.

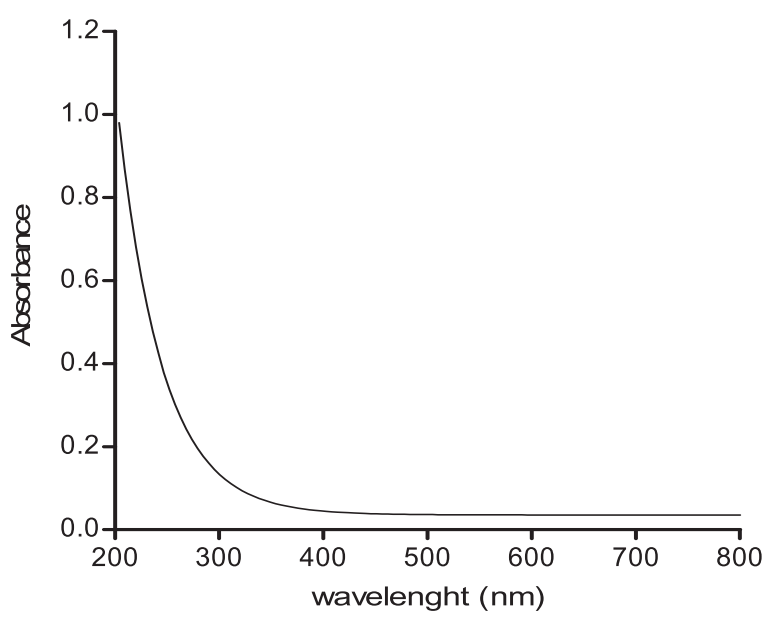

Fig. 3. UV-Vis spectrum of the purified yerba mate polysaccharide.

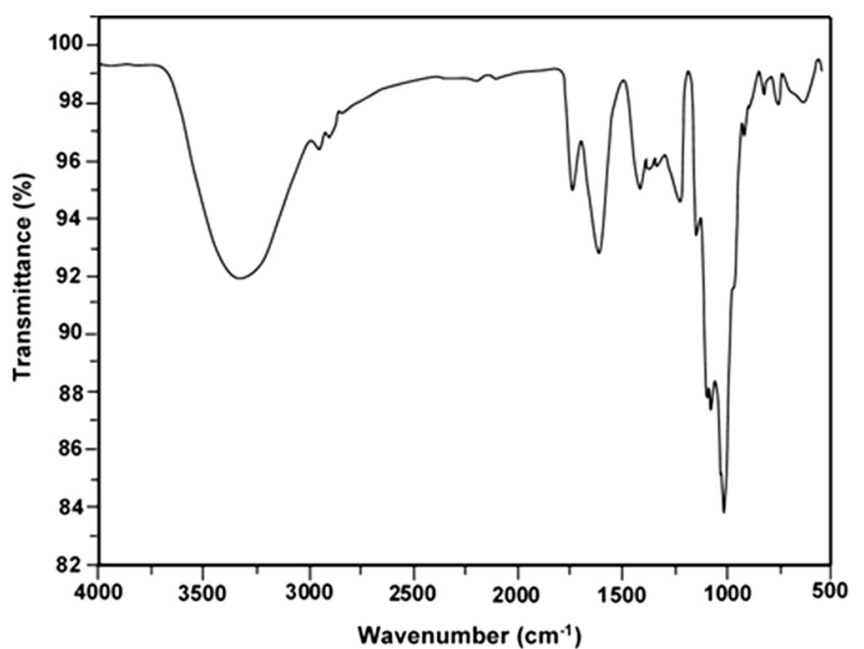

Fig. 4. FTIR spectrum of the purified yerba mate polysaccharide.

$0.05 \mathrm{mg} / \mathrm{mL}$ and $3.36 \pm 0.31 \mathrm{mg} / \mathrm{mL}$, respectively. FRAP and ORAC, expressed as equivalents of Trolox, were $20.84 \pm 1.61 \mu \mathrm{M} \mathrm{TE} / \mathrm{mg}$ and $556.30 \pm 12.83 \mu \mathrm{M} \mathrm{TE} / \mathrm{mg}$, respectively.

The mechanism by which polysaccharides act as antioxidants is still not a consensus among researchers. While some researchers strongly relate the structures of the polysaccharides to their antioxidant activity $[36,37]$, others suggest that the antioxidant activities of complex carbohydrates should be attributed to their phenolic and protein components or contaminants rather than to the carbohydrate moieties, especially when the analyses were carried out using crude or semi-purified polysaccharides [16,38-40]. Recent analyses conducted with the highly homogeneous polysaccharide fractions from Ilex latifolia [36] Mesona chinensis [37], Bryopsis plumose [41], Malva aegyptiaca [42], Plantago notata [43], Dendrobium officinale [44], and Schisandra sphenanthera [45] have confirmed antioxidant activities of polysaccharides evaluated by different methods. The mechanisms involved, however, remain largely unknown. In general, functional groups such as $-\mathrm{OH},-\mathrm{COOH}$ and $\mathrm{C}=\mathrm{O}$, largely found in polysaccharides in addition to anionic and cationic functional groups, such as uronic acids, have been related to the antioxidant activities of polysaccharides [35]. Moderate molecular weight, water solubility, triple helix stereo-configuration and higher degrees of branching are also considered factors that might favour antioxidant activity [45].

\subsection{Antimicrobial activities of the yerba mate polysaccharide}

Antibacterial and antifungal activities of the YM polysaccharide are presented in Tables 1 and 2, respectively. The polysaccharide had prominent antimicrobial effects against Gram-negative bacteria (Enterobacter cloacae, Salmonella enteritidis, and Salmonella typhimurium), Grampositive bacteria (Bacillus cereus, Micrococcus flavus, Staphylococcus aureus, and Listeria monocytogenes) and against Aspergillus fumigatus, Aspergillus versicolor, Aspergillus ochraceus, Aspergillus niger, Candida crusei, Penicillium funiculosum, and Penicillium verrucosum var. cyclopium. According to MIC values, bioactive extracts from natural products can be classified into strong inhibitors (MIC below $0.5 \mathrm{mg} / \mathrm{mL}$ ), moderate inhibitors (MIC between 0.6 and $1.5 \mathrm{mg} / \mathrm{mL}$ ) and weak inhibitors (MIC above $1.6 \mathrm{mg} / \mathrm{mL}$ ) [25]. According to these parameters, the herein assessed YM polysaccharide can be considered a strong inhibitor against B. cereus, $M$. flavus, E cloacae, S. enteritidis and S. typhimurium; however, a weak inhibitor of $E$. coli. Regarding the antifungal bioassays, the YM polysaccharide seems to be a strong inhibitor against all tested fungi, except for $A$. niger.

It was reported elsewhere that the YM polysaccharide prevents lethality caused by poly-microbial sepsis in mice, which was attributed to its action in reducing the neutrophil infiltration, on its turn an 

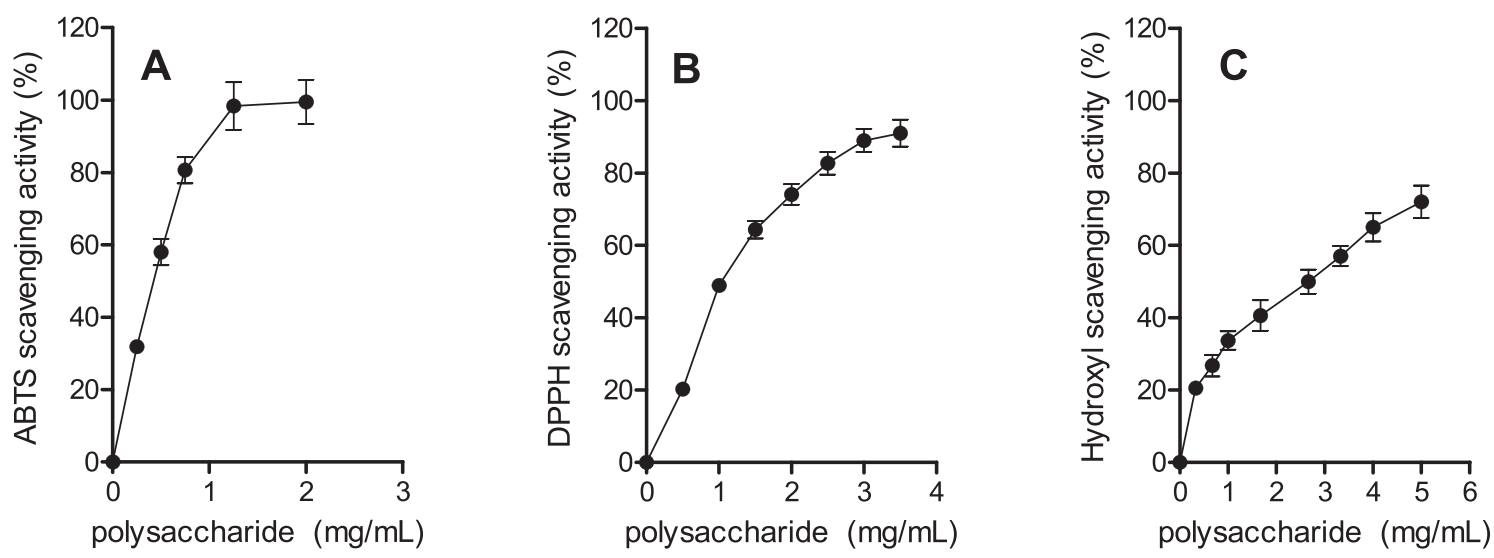

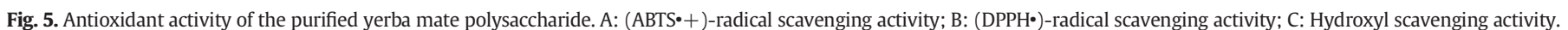

important alteration associated to sepsis [13]. Although there is no doubt that diminution of neutrophil infiltration may be beneficial in sepsis, an equal or even higher weight must be attributed to the observed antimicrobial action of the polysaccharide. After all, an antimicrobial effect represents a direct action on the infectious agents, which, in principle, is more effective than indirect and marginal mechanisms such as neutrophil infiltration.

Antimicrobial activities have also been described for polysaccharides isolated from Quercus brantii leaves [46], Olea europaea leaves [47], Capparis spinosa leaves [48], and Malva aegyptiaca leaves [42]. The mechanisms involved in the antimicrobial activity of polysaccharides are worthy of further investigations. Differences in the cell membrane composition and structure can explain the slightly greater resistance among Gram-positive bacteria $[48,49]$. The YM polysaccharide showed antibacterial activity against all tested strains, except to $E$. coli. This result suggests that the inhibition of iron absorption by the bacteria is a possible mechanism of the antibacterial activity of polysaccharides. Iron is an important element for bacterial growth and the enterobactin secreted by E. coli has a high affinity for iron and can compete with the chelating activity of polysaccharides [50].

\subsection{Antiproliferative and cytotoxic actions of the yerba mate polysaccharide}

The YM polysaccharide did not show hepatotoxicity in PLP2 cells, up to the maximum concentration tested $\left(\mathrm{GI}_{50}>400 \mathrm{mg} / \mathrm{mL}\right)$, what endorses its safe use in the case of potential applications as a food additive or nutraceutical. The same is valid for the four tumor human cell lines assessed namely MCF-7, NCI-H460, HeLa and HepG2 (GI

Table 1

Antibacterial activity of the yerba mate polysaccharide.

\begin{tabular}{|c|c|c|c|c|c|c|}
\hline \multirow[t]{2}{*}{ Compounds } & \multicolumn{2}{|c|}{$\begin{array}{l}\text { YM } \\
\text { polysaccharide }\end{array}$} & \multicolumn{2}{|c|}{ Streptomycin } & \multicolumn{2}{|c|}{ Ampicillin } \\
\hline & MIC & $\mathrm{MBC}$ & MIC & $\mathrm{MBC}$ & MIC & MBC \\
\hline \multicolumn{7}{|l|}{ Gram positive } \\
\hline Bacillus cereus & 0.30 & 0.40 & 0.10 & 0.20 & 0.25 & 0.40 \\
\hline Micrococcus flavus & 0.30 & 0.40 & 0.20 & 0.30 & 0.25 & 0.40 \\
\hline Staphylococcus aureus & 0.60 & 0.80 & 0.04 & 0.10 & 0.25 & 0.45 \\
\hline Listeria monocytogenes & 0.60 & 0.80 & 0.20 & 0.30 & 0.40 & 0.50 \\
\hline \multicolumn{7}{|l|}{ Gram negative } \\
\hline Escherichia coli & $>1.60$ & $>1.60$ & 0.20 & 0.30 & 0.40 & 0.50 \\
\hline Enterobacter cloacae & 0.30 & 0.40 & 0.20 & 0.30 & 0.25 & 0.50 \\
\hline Salmonella enteritidis & 0.40 & 0.60 & 0.15 & 0.30 & 0.30 & 0.60 \\
\hline Salmonella typhimurium & 0.40 & 0.60 & 0.25 & 0.50 & 0.40 & 0.75 \\
\hline
\end{tabular}

$\mathrm{MIC}=$ minimum inhibitory concentration $(\mathrm{mg} / \mathrm{mL}) ; \mathrm{MBC}=$ minimum bactericidal concentration $(\mathrm{mg} / \mathrm{mL})$
$>400 \mathrm{mg} / \mathrm{mL}$ ). However, there are reports on the direct action of polysaccharides on the tumor cells or by enhancing the immune function of the organism, exerting thus an indirect antitumor activity [51]. Different rhamnogalacturan I and II type polysaccharides (RG-I and RG-II) have been described as possessing potentially antitumoral activities. For example, a RG-II-type polysaccharide isolated from mature leaves of green tea, presented antitumor and anti-metastatic activities via activation of macrophages and natural killer cells [52]. RG-II isolated from the leaves of Panax ginseng inhibited tumor growth by activating dendritic cell-mediated $\mathrm{CD}^{+}{ }^{+} \mathrm{T}$ cells [53]. Furthermore, a RG-I domain-rich pectin from potato inhibited the proliferation of HT-29 cells and induced significant G2/M cell cycle arrest [54]. Our results suggest that the YM polysaccharide does not act directly on the tumor cell. However, it could be able to act indirectly if one takes into account what was found for the RG-II-type polysaccharide from green tea leaves. Additional approaches are necessary to clarify this question.

\section{Conclusion}

The results of the present work indicate that the YM polysaccharide possesses antioxidant activities corroborated by different in vitro methods. The YM polysaccharide also presents antibacterial and antifungal activities, which can help to explain mitigation of sepsis caused by this macromolecule according to a previous report. For these and other reasons, the YM polysaccharide can be considered to be potentially useful for the pharmaceutical and food industries.

\section{Conflicts of interest}

The authors declare no conflict of interests.

Table 2

Antifungal activity of the yerba mate polysaccharide.

\begin{tabular}{|c|c|c|c|c|c|c|}
\hline \multirow[t]{2}{*}{ Compound } & \multicolumn{2}{|c|}{$\begin{array}{l}\text { YM } \\
\text { polysaccharide }\end{array}$} & \multicolumn{2}{|c|}{ Ketoconazole } & \multicolumn{2}{|c|}{ Bifonazole } \\
\hline & MIC & MFC & MIC & MFC & MIC & MFC \\
\hline Aspergillus fumigatus & 0.40 & 0.60 & 0.25 & 0.50 & 0.15 & 0.20 \\
\hline Aspergillus versicolor & 0.20 & 0.40 & 0.20 & 0.50 & 0.10 & 0.20 \\
\hline Aspergillus ochraceus & 0.40 & 0.60 & 1.50 & 2.00 & 0.15 & 0.20 \\
\hline Aspergillus niger & 0.60 & 0.80 & 0.20 & 0.50 & 0.15 & 0.20 \\
\hline Candida crusei & 0.30 & 0.40 & 0.075 & 0.15 & 0.05 & 0.10 \\
\hline Penicillium funiculosum & 0.40 & 0.60 & 0.20 & 0.50 & 0.20 & 0.25 \\
\hline Penicillium verrucosum var. cyclopium & 0.30 & 0.60 & 0.20 & 0.30 & 0.10 & 0.20 \\
\hline
\end{tabular}

$\mathrm{MIC}=$ minimum inhibitory concentration $(\mathrm{mg} / \mathrm{mL}) ; \mathrm{MFC}=$ minimum fungicidal concentration $(\mathrm{mg} / \mathrm{mL})$ 


\section{Acknowledgments}

The authors thank the Conselho Nacional de Desenvolvimento Científico e Tecnológico (CNPq, Proc. 3079/2015-8) for funding this study. Author V.G. Correa thanks Coordenação de Aperfeiçoamento do Pessoal do Ensino Superior (CAPES) for the financial support provided for their post-graduate studies in Universidade Estadual de Maringá. R.C.G. Corrêa thanks CAPES Foundation, Ministry of Education, Brazil (process number 88881.120010/2016-01) for funding her postdoctoral internship in Polytechnic Institute of Bragança. A. Bracht, R.A. Peralta and R.M. Peralta are research grant recipients of CNPq.

\section{References}

[1] N. Bracesco, A.G. Sanchez, V. Contreras, T. Menini, A. Gugliucci, Recent advances on Ilex paraguariensis research: minireview, J. Ethnopharmacol. 136 (2011) 378-384.

[2] N.S. Lima, E. Oliveira, A.P. Silva, L.A. Maia, E.G. Moura, P.C. Lisboa, Effects of Ilex paraguariensis (yerba mate) treatment on leptin resistance and inflammatory parameters in obese rats primed by early weaning, Life Sci. 12 (115) (2014) 29-35.

[3] L. Bravo, L. Goya, E. Lecumberri, LC/MS characterization of phenolic constituents of mate (Ilex paraguariensis A. St.-Hill) and its antioxidant activity compared to commonly consumed beverages, Food Res. Int. 40 (2007) 303-405.

[4] A.C.P. Piovezan-Borges, C. Valério-Júnior, I.L. Gonçalves, A.A. Mielniczki-Pereira, A.T. Valduga, Antioxidant potential of yerba mate (Ilex paraguariensis St. Hil.) extracts in Saccharomyces cerevisae deficient in oxidant defense genes, Braz. J. Biol. 76 (2016) 539-544.

[5] S.F.L. Paganini Stein, B. Schmidt, E.B. Furlong, L.A. Souza-Soares, M.C. Soares, M.R. Vaz, A.L. Muccillo Baisch, Vascular responses to extractable fractions of Ilex paraguariensis in rats fed standard and high-cholesterol diets, Biol. Res. Nurs. 7 (2005) 146-156.

[6] S.I. Yu, S.W. Yue, Z. Liu, T. Zhang, N. Xiang, H. Fu, Yerba mate (Ilex paraguariensis) improves microcirculation of volunteers with high blood viscosity: a randomized, double-blind, placebo-controlled trial, Exp. Gerontol. 62 (2015) 14-22.

[7] G.A. Klein, A. Stefanuto, B.C. Boaventura, E.C. Morais, L.S. Cavalcante, F. Andrade, E. Wazlawik, P.F. Di Pietro, M. Maraschin, E.L. Silva, Mate tea (Ilex paraguariensis) improves glycemic and lipid profiles of type 2 diabetes and pre-diabetes individuals: a pilot study, J. Am. Coll. Nutr. 30 (2011) 320-332.

[8] A.N. Murakami, R.D. Amboni, E.S. Prudêncio, E.R. Amante, C.B. Fritzen-Freire, B.C. Boaventura, I.B. Muñoz, C.S. Branco, M. Salvador, M. Maraschin, Concentration of biologically active compounds extracted from Ilex paraguariensis St Hil. by nanofiltration, Food Chem. 141 (2013) 60-65.

[9] G.D. Pimentel, F.S. Lira, J.C. Rosa, A.V. Caris, F. Pinheiro, E.B. Ribeiro, C.M. Oller do Nascimento, L.M. Oyama, Yerba mate extract (Ilex paraguariensis) attenuates both central and peripheral inflammatory effects of diet-induced obesity in rats, J. Nutr. Biochem. 24 (2013) 809-818.

[10] N.L. Lunceford, A. Gugliucci, Ilex paraguariensis extracts inhibit AGE formation more efficiently than green tea, Fitoterapia 76 (2005) 419-427.

[11] V.G. Correa, G.A. Gonçalves, A.B. Sá-Nakanishi, I.C.F.R. Ferreira, L. Barros, M.I. Dias, E.A. Koehnlein, C.G.M. Souza, A. Bracht, R.M. Peralta, Effects of in vitro digestion and in vitro colonic fermentation on stability and functional properties of yerba mate (Ilex paraguariensis A. St. Hil.) beverages, Food Chem. 237 (2017) 453-460.

[12] A.H.P. Souza, R.C.G. Corrêa, L. Barros, R.C. Calhelha, C. Santos-Buelga, R.M. Peralta, A Bracht, M. Matsushita, I.C.F.R. Ferreira, Phytochemicals and bioactive properties of Ilex paraguariensis: an in-vitro comparative study between the whole plant, leaves and stems, Food Res. Int. 78 (2015) 286-294.

[13] N. Dartora, L.M. Souza, S.M.M. Paiva, C.T. Scoparo, M. Iacomini, P.A.J. Gorin, Y.D. Rattmann, G.L. Sassaki, Rhamnogalacturonan from Ilex paraguariensis: a potential adjuvant in sepsis treatment, Carbohydr. Polym. 92 (2013) 1776-1782.

[14] D. Maria-Ferreira, N. Dartora, L.M. Silva, I.T. Pereira, L.M. Souza, D.S. Ritter, M. Iacomini, M.F.P. Werner, G.L. Sassaki, C.H. Baggio, Chemical and biological characterization of polysaccharides isolated from Ilex paraguariensis A. St.-Hil, Int. J. Biol. Macromol. 59 (2013) 125-133.

[15] B.M. Yapo, Rhamnogalacturonan-I: a structurally puzzling and functionally versatile polysaccharide from plant cell walls and mucilages, Polym. Rev. 51 (2011) 391-413.

[16] H. Wang, Y.M. Liu, Z.M. Qi, S.Y. Wang, S.X. Liu, X. Li, H.J. Wang, X.C. Xia, An overview on natural polysaccharides with antioxidant properties, Curr. Med. Chem. 20 (2013) 2899-2913.

[17] J. Liu, S. Willför, C. Xu, A review of bioactive plant polysaccharides: biological activities, functionalization, and biomedical applications, Bioact. Carbohydr. Diet. Fibre 5 (2015) 31-61.

[18] L. Shi, Bioactivities, isolation and purification methods of polysaccharides from natural products: a review, Int. J. Biol. Macromol. 92 (2016) 37-48.

[19] J.-H. Xie, M.-L. Lin, G.A. Morris, X.-Q. Zha, H.-Q. Chen, Y. Yi, J.-E. Li, Z.-J. Wang, J. Gao, S.-P. Nie, P. Shang, M.-Y. Xie, Advances on bioactive polysaccharides from medicinal plants, Crit. Rev. Food Sci. Nutr. 56 (1) (2016) S60-84

[20] M. Wang, S. Zhao, P. Zhy, C. Nie, S. Ma, N. Wang, X. Du, Y. Zhou, Purification, characterization and immunomodulatory activity of water extractable polysaccharides from the swollen culms of Zizania latifolia, Int. J. Biol. Macromol. 107 (2018) 882-890.

[21] H. Mu, A. Zhang, W. Zhang, G. Cui, S. Wang, J. Duan, Antioxidative properties of crude polysaccharides from Inonotus obliquus, Int. J. Mol. Sci. 13 (2012) 9194-9206

[22] V.L. Singleton, J.A., Colorimetry of total phenolics with phosphomolybdicphosphotungstic acid reagents, Am. J. Enol. Vitic. 16 (1965) 144-158.
[23] M.M. Bradford, A rapid and sensitive method for the quantitation of microgram quantities of protein utilizing the principle of protein-dye binding, Anal. Biochem. 72 (1976) 248-254.

[24] E.A. Koehnlein, E.M. Koehnlein, R.C. Gomes, V.S. Nishida, V.G. Correa, A. Bracht, R.M. Peralta, Analysis of a whole diet in terms of phenolic content and antioxidant capacity: effects of a simulated gastrointestinal digestion, Int. J. Food Sci. Nutr. 67 (2016) 614-623.

[25] R.C.G. Corrêa, C.W.I. Haminiuk, L. Barros, M.I. Dias, R.C. Calhelha, C.G. Kato, V.G. Correa, R.M. Peralta, I.C.F.R., Stability and biological activity of Merlot (Vitis vinifera) grape pomace phytochemicals after simulated in vitro gastrointestinal digestion and colonic fermentation, J. Funct. Foods 36 (2017) 410-417.

[26] Approved standard, in: CLSI (Ed.), CLSI Publication M07-A8, 8th ed.Clinical and Laboratory Standards Institute, Wayne, PA, 2009.

[27] D.S. Stojković, N. Kovačević-Grujičić, F.S. Reis, S. Davidović, L. Barros, J. Popović, I Petrović, A. Pavić, J. Glamočlija, A. Ćirić, M. Stevanović, I.C.F.R. Ferreira, M. Soković, Chemical composition of the mushroom Meripilus giganteus Karst. and bioactive properties of its methanolic extract, LWT Food Sci. Technol. 79 (2017) 454-462.

[28] L. Barros, I.C.F.R. Ferreira, C. Pereira, Optimized analysis of organic acids in edible mushrooms from Portugal by ultra fast liquid chromatography and photodiode array detection, Food Anal. Methods 6 (2013) 309-316.

[29] R.M.V. Abreu, I.C.F.R. Ferreira, R.C. Calhelha, R.T. Lima, M.H. Vasconcelos, F. Adega, R. Chaves, M.-J.R.P. Queiroz, Anti-hepatocellular carcinoma activity using human HepG2 cells and hepatotoxicity of 6-substituted methyl 3-aminothieno [3,2-b]pyridine-2-carboxylate derivatives: in vitro evaluation, cell cycle analysis and QSAR studies, Eur. J. Med. Chem. 46 (2011) (2011) 5800-5806.

[30] S.A. Barker, E.J. Bourne, M. Stacey, Infra-red spectra of carbohydrates. Part I. Some derivatives of D-glucopyranose, J. Chem. Soc. 1 (1954) 171-176.

[31] M.A. Coimbra, F. Gonçalves, A.S. Barros, I. Delgadillo, Fourier transform infrared spectroscopy and chemometric analysis of white wine polysaccharide extracts, J. Agric. Food Chem. 50 (2002) 3405-3411.

[32] Y.D. Sun, Z.H. Wang, Q.S. Ye, Composition analysis and anti-proliferation activity of polysaccharides from Dendrobium chrysotoxum, Int. J. Biol. Macromol. 62 (2013) 291-295.

[33] Z. Liu, J. Dang, Q. Wang, M. Yu, L. Jiang, L. Mei, Y. Shao, Y. Tao, Optimization of polysaccharides from Lycium ruthenicum fruit using RSM and its anti-oxidant activity, Int. J. Biol. Macromol. 61 (2013) 127-134.

[34] Z. Zhan-Yi, H. Long-Tao, D. Lu-Lu, L. Shu-Lin, Functional groups and antioxidant activities of polysaccharides from five categories of tea, Ind. Crop. Prod. 58 (2014) $31-35$.

[35] J. Wang, S. Hu, S. Nie, Q. Yu, M. Xie, Reviews on mechanisms of in vitro antioxidant activity of polysaccharides, Oxidative Med. Cell. Longev. (2015), 5692825. (13 pp.).

[36] J. Fan, Z. Wu, T. Zhao, Y. Sun, H. Ye, R. Xu, X. Zeng, Characterization, antioxidant and hepatoprotective activities of polysaccharides from Ilex latifolia Thunb, Carbohydr. Polym. 101 (2014) 990-997.

[37] L. Lin, J. Xie, S. Liu, M. Shen, W. Tang, M. Xie, Polysaccharide from Mesona chinensis: extraction optimization, physicochemical characterizations and antioxidant activities, Int. J. Biol. Macromol. 99 (2017) 665-673.

[38] S.P. Nie, M.Y. Xie, A review on the isolation and structure of tea polysaccharides and their bioactivities, Food Hydrocoll. 25 (2011) 144-149.

[39] V.V. Smirnov, V.V. Golovchenko, F.V. Vityazev, O.A. Patova, N.Y. Selivanov, O.G. Selivanova, S.V. Popov, The antioxidant properties of pectin fractions isolated from vegetables using a simulated gastric fluid, J. Chem. (2017), 5898594. (10 pp.).

[40] J.B. Xiao, H. Jiang, A review on the structure-function relationship aspect of polysaccharides from tea materials, Crit. Rev. Food Sci. Nutr. 55 (2015) 930-938.

[41] H. Song, Q. Zhang, Z. Zhang, J. Wang, In vitro antioxidant activity of polysaccharides extracted from Bryopsis plumose, Carbohydr. Polym. 80 (2010) 1057-1061.

[42] N. Fakhfakh, O. Abdelhedi, H. Jdir, M. Nasri, N. Zouari, Isolation of polysaccharides from Malva aegyptiaca and evaluation of their antioxidant and antibacterial properties, Int. J. Biol. Macromol. 105 (2017) 1519-1525.

[43] Z. Boual, A. Kemassi, M.D. Bouhoun, P. Michaud, M.D.O. Hadj, Isolation and partial characterization of water soluble polysaccharides from one saharian medicinal plant: Plantago notata Lagasca, Int. Conf. Environ. Chem. Biol. 49 (2012) 420-424.

[44] O.Z. Luo, Z. Tang, X. Zhang, Y. Zhong, S. Yao, L. Wang, C. Lin, X. Luo, Chemical properties and antioxidant activity of a water-soluble polysaccharide from Dendrobium officinale, Int. J. Biol. Macromol. 89 (2016) 219-227.

[45] T. Zhao, G. Mao, W. Feng, R. Mao, X. Gu, T. Li, Q. Li, Y. Bao, L. Yang, X. Wu, Isolation, characterization and antioxidant activity of polysaccharide from Schisandra sphenanthera, Carbohydr. Polym. 105 (2018) 26-33.

[46] S. Tahmouzi, Optimization of polysaccharides from Zagros oak leaf using RSM: antioxidant and antimicrobial activities, Carbohydr. Polym. 106 (2014) 238-246.

[47] I. Khemakhem, O. Abdelhedi, I. Trigui, M.A. Ayadi, Structural, antioxidant and antibacterial activities of polysaccharides extracted from olive leaves, Int. J. Biol. Macromol. 106 (2018) 325-432.

[48] F. Mazarei, H. Jooyandeh, M. Noshad, M. Hojjati, Polysaccharide of caper (Capparis spinosa L.) leaf: extraction optimization, antioxidant potential and antimicrobial activity, Int. J. Biol. Macromol. 95 (2017) 224-231.

[49] S. Tahmouzi, M. Ghodsi, Optimum extraction of polysaccharides from motherwort leaf and its antioxidant and antimicrobial activities, Carbohydr. Polym. 112 (2014) 396-403.

[50] L.L. Shao, J. Xu, M.J. Shi, X.L. Wang, Y.T. Li, L.M. Kong, R.C. Hider, T. Zhou, Preparation, antioxidant and antimicrobial evaluation of hydroxamated degraded polysaccharides from Enteromorpha prolifera, Food Chem. 237 (2017) 481-487.

[51] L. Chen, G. Huang, Antitumor activity of polysaccharides: an overview, Curr. Drug Targets 19 (2018) 89-96.

[52] H.-R. Park, D. Hwang, H.-J. Suh, K.-W. Yu, T.Y. Kim, K.-S. Shina, Antitumor and antimetastatic activities of rhamnogalacturonan-II-type polysaccharide isolated 
from mature leaves of green tea via activation of macrophages and natural killer cells, Int. J. Biol. Macromol. 99 (2017) 179-186.

[53] S.N. Park, K.T. Noh, Y.I. Jeong, I.D. Jung, H.K. Kang, G.S. Cha, S.J. Lee, J.K. Seo, D.H. Kang, T.-H. Hwang, E.Y. Lee, B. Kwon, Y.-M. Park, Rhamnogalacturonan II is a Toll-like receptor 4 agonist that inhibits tumor growth by activating dendritic cell-mediated CD8+ T cells, Exp. Mol. Med. 45 (2013), e8.
[54] H. Cheng, Z. Zhang, J. Ling, D. Liu, M. Hao, X. Gao, G. Tai, Y. Zhou, The inhibitory effects and mechanisms of rhamnogalacturonan I pectin from potato on HT-29 colon cancer cell proliferation and cell cycle progression, Int. J. Food Sci. Nutr. 64 (2013) 36-43. 